\title{
МИНЕРАЛЬНО-ГЕОХИМИЧЕСКАЯ ЗОНАЛЬНОСТЬ ЗОЛОТОНОСНЫХ КОР ВЫВЕТРИВАНИЯ ТОМЬ-ЯЙСКОГО МЕЖДУРЕЧЬЯ
}

\author{
Янченко Ольга Михайловна', \\ olmininayanchenko@mail.ru \\ Ворошилов Валерий Гаврилович', \\ v_g_v@tpu.ru
}

Тимкин Тимофей Васильевич', timkin@tpu.ru

\author{
Зиаии Мансур², \\ m.ziaii47@gmail.com \\ 1 Национальный исследовательскмй Томский политехнический университет, \\ Россия, 634050, г. Томск, пр. Ленина, 30. \\ 2 Шахрудский технологический университет, \\ Иран, 3619995161, Болвар Данешка, Шахруд.
}

\begin{abstract}
Актуальность. Коры выветривания Томь-Яйского междуречья могут быть объектами промышленной добычи золота. В ТомьЯйском междуречье коры выветривания широко распространены, установлена их золотоносность, но строение, минеральный состав и геохимические особенности изучены недостаточно.

Цель: выявить минерально-геохимическую зональность кор выветривания Томь-Яйского междуречья для решения вопросов генезиса и разработки критериев прогнозирования их золотоносности.

Объект: коры выветривания по породам палеозойского фундамента Томь-Яйского междуречья.

Методы. Кристалломорфологические особенности золота и минералов-спутников, парагенетические ассоциации минералов изучались микроскопически под бинокуляром, в отраженном свете, химический состав минералов- методом ИСП-масс-спектрометрии, на рентгено-флюоресцентном микроскопе HORIBA Scientific XGT-7200, сканирующем электронном микроскопе TESCAN VEGA 3 SBU с ЭДC OXFORD X-Maх 50. Сокращенный химический состав продуктов выветривания определялся методом ИСП-масс-спектрометрии. Минеральный состав пелитовой фракции определялся методом рентгенофазового количественного анализа на дифрактометре D8 Advance фирмы Bruker. Проведен сокращенный гранулометрический анализ продуктов выветривания разных зон профиля.

Результаты. В Томь-Яйском междуречье установлены остаточные и переотложенные коры выветривания. Продукты выветривания представлены песчано-алевритовым, глинистым и щебнисто-дресвяным материалом, с преобладанием песчаной и алеврито-глинистой составляющей. Установлен состав и распределение по разрезу глинистых минералов, карбонатов, пирита, золота и других минералов. Состав остаточных кор выветривания монтмориллонит-гидрослюдисто-каолинитовый. В строении полного профиля выделяются зоны: 1) дезинтеграции, 2) гидратации и 3) гидролиза. Дана минерально-геохимическая характеристика выделенных зон. На основании сокращенного химического анализа рассчитаны основные геохимические модули.
\end{abstract}

\section{Ключевые слова:}

Остаточная кора выветривания, переотложенная кора выветривания, золото, минерально-геохимическая зональность, Томь-Яйское междуречье.

\section{Введение}

Золотоносные коры выветривания - новый для Томской области геолого-промышленный тип месторождений золота, которому в настоящее время уделяется большое внимание. Это обусловлено близповерхностным залеганием, высокой дифференциацией вещества с высвобождением золота, его облагораживанием и укрупнением, что обеспечивает высокую экономическую эффективность отработки подобных месторождений, прежде всего открытым способом. В то же время многие теоретические вопросы накопления золота в корах выветривания являются дискуссионными. В Томь-Яйском междуречье коры выветривания широко развиты, золотоносность их установлена, но изучена слабо, этим и определяется актуальность исследования. Наиболее детально коры выветривания изучены нами в цен- тральной части Томь-Яйского междуречья, в пределах Халдеевской и Ушайской площадей (рис. 1).

Целью данного исследования является получение дополнительных сведений о строении профиля коры выветривания, особенностях его геохимической и минералогической зональности для решения вопросов генезиса и прогноза рудоносности кор выветривания.

\section{Геологическое строение района}

В региональном плане изучаемый район находится в области сочленения крупных геологических структур - Колывань-Томской складчатой зоны, Западно-Сибирской плиты, Кузнецкого прогиба и Кузнецкого Алатау. В геологическом строении принимают участие вещественные комплексы трех структурных этажей. 
Нижний структурный этаж образован докембрийскими и кембрийскими сложнодислоцированными вулканогенно-осадочными отложениями север-северо-западного простирания, выходящими на поверхность в пределах Яйского горста, продолжающего структуры Кузнецкого Алатау.

Средний структурный этаж представлен девонкаменноугольными отложениями Колывань-Томской складчатой зоны, Кузнецкого Алатау и Кузнецкого прогиба. Структуры Кузнецкого прогиба проявлены в виде вытянутых в субмеридиональном направлении грабен-синклиналей: Ташминской на севере и Анжерской на юге района. На востоке эти структуры надвинуты на Яйский горст, а на западе через Томский надвиг перекрыты вулканогенно-осадочными толщами Колывань-Томской шарьяжно-складчатой зоны. Колывань-Томская складчатая зона представлена серией надвиговых пластин, сложенных отложениями митрофановской, лебедянской, пачинской и юргинской свит. Западной границей структуры является круто па- дающий на запад Халдеевский разлом, восточной - Томский надвиг. Западнее Колывань-Томская складчатая зона представлена Томским синклинорием (прогибом). В пределах синклинория выделяется ряд син- и антиклинальных складок, основными из которых являются: Луговая, Лязгинская и Богашевская антиклинали, сложенные в ядре углеродистыми алевролитами ярской-саламатовской толщ, и Корниловская и Петуховская синклинали, слагаемые породами лагерносадской и басандайской свит.

В смятых в складки терригенных отложениях проявлены разрывные структуры, которые подразделяются на три основные группы: 1) продольные син- и послескладчатые, пермского возраста, связанные с формированием Колывань-Томской складчатой зоны и Томского синклинория; 2) рифтогенные, триасового возраста, обусловленные развитием Сибирского суперплюма, заложением Западно-Сибирской плиты и формированием томского комплекса даек и силлов. 3) неотектонические,

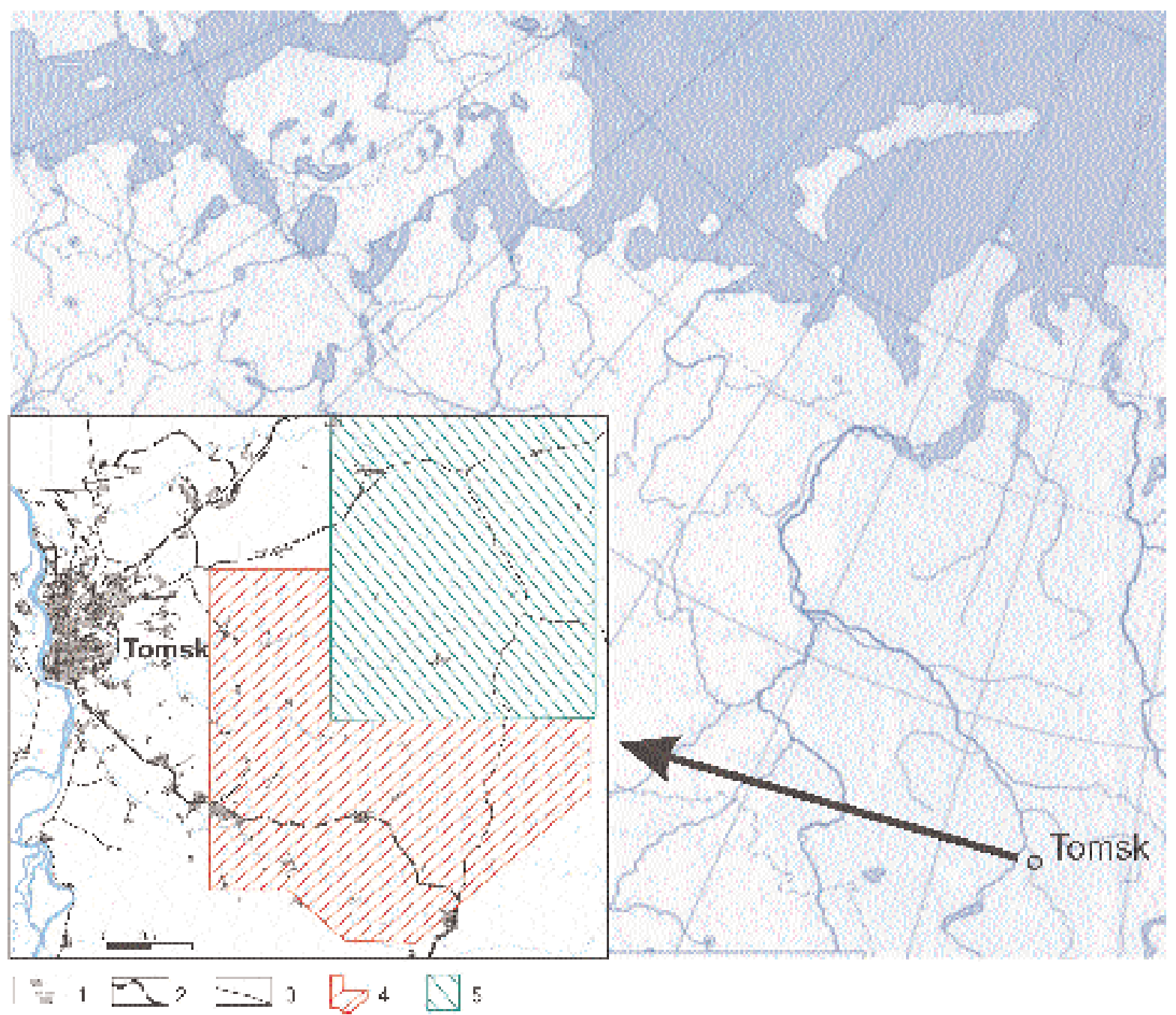

Рис. 1. Обзорная карта: 1 - населенные пункты; 2 - железная дорога; 3 - шоссейные дороги; 4 - Ушайская площадь; 5 - Халдеевская площадь

Fig. 1. Overview map: 1 - settlements; 2 - railway; 3 - highways; 4 - Ushayskaya area; 5 - Khaldeevskaya area 
эпиплатформенные олигоцен-эоплейстоценового возраста.

Верхний структурный этаж представлен отложениями меловой, палеогеновой, неогеновой и четвертичной систем платформенного чехла Западно-Сибирской плиты.

Разрывные нарушения в верхнекайнозойских рыхлых и слабоуплотненных осадках проявляются в виде флексурно-разрывных зон. Наиболее значительная активизация этой системы разломов произошла в олигоцене и в конце неогена-эоплейстоцене. В результате произошла существенная эрозия кор выветривания и их переотложение в виде аллювиально-пролювиальных отложений нижней части новомихайловской свиты, евсинской и кирсановской свит [1].

\section{Фактический материал и методы исследования}

Фактическим материалом для проведения исследования послужили керновые пробы 98 скважин, бороздовые и задирковые пробы 23 канав. Проведен сокращенный полуколичественный минералогический анализ более 900 шлихов из керновых, бороздовых и задирковых проб, отобраны мономинеральные фракции карбонатов, пирита и золота. Керновые, бороздовые, задирковые пробы и шлихи-концентраты проб анализировались в Химико-аналитическом центре «Плазма» (г. Томск) методом ИСП-масс-спектрометрии на 25 элементов. Работы проводились на масс-спектрометрометрах ELAN-9000 DRC-e, Agilent-7700x, Agilent-7900. Методом ИСП-масс-спектрометрии определен сокращенный химический состав продуктов выветривания $\left(\mathrm{SiO}_{2}, \mathrm{Al}_{2} \mathrm{O}_{3}, \mathrm{TiO}_{2}, \mathrm{Fe}_{2} \mathrm{O}_{3}\right)$, элементы-примеси и химический состав монофракций минералов. На сканирующем электронном микроскопе TESCAN VEGA 3 SBU с ЭДC OXFORD $\mathrm{X}$-Max 50 и рентгено-флюоресцентном микроскопе HORIBA Scientific XGT-7200 в Национальном исследовательском Томском политехническом университете (НИ ТПУ) изучен химический состав и внутренняя структура золота и минералов-спутников. Определение гранулометрического (зернового) состава, содержания крупнозернистых включений, определение остатка на сите 0,063 мм и тонкодисперсных фракций в глинистых продуктах выветривания проводилось в Химико-аналитическом центре «Плазма» и Аналитико-технологическом сертификационном испытательном центре ФГУП «ЦНИИгеолнеруд» (г. Казань). Минеральный состав пелитовой фракции определялся методом рентгенофазового количественного анализа на дифрактометре D8 Advance фирмы Bruker в Аналитико-технологическом сертификационном испытательном центре ФГУП «ЦНИИгеолнеруд» и на установке рентгеноструктурного анализа (ДРОН-ЗМ) в НИ ТПУ.

\section{Характеристика кор выветривания}

В Томь-Яйском междуречье практически повсеместно на породах палеозойского фундамента развиты остаточные коры выветривания площадного и линейного типов мел-палеогенового возраста, на отдельных участках присутствуют продукты ближайшего переотложения этих кор. Остаточная кора выветривания, как правило, часто представлена только зоной дезинтеграции мощностью в первые метры, либо полностью эродирована на участках, приуроченных к долинам современных рек. Мощность и строение кор выветривания изменяется в зависимости от литологического состава и степени проницаемости материнских пород. Полный профиль выветривания проявляется в зонах повышенной проницаемости исходных пород, связанных с тектоническими нарушениями, в некоторых случаях залеченных интрузивными образованиями базитового состава. В полном профиле остаточной коры выветривания выделяются снизу вверх следующие зоны: дезинтеграции, гидратации и гидролиза. Сокращенный профиль характеризуется развитием неполного числа зон [2].

Площадные остаточные коры выветривания Халдеевской площади представлены породами зон дезинтеграции и гидратации, то есть в различной степени выветрелыми породами юргинской и басандайской, реже пачинской и митрофановской свит, замещаемыми по зонам трещиноватости гидрослюдами, что приводит к осветлению пород черные, темно-серые алевролиты и песчаники превращаются светло-серые, желтовато-бурые гидрослюдизированные породы, сохраняющие структуру замещаемых пород. Мощность площадных кор выветривания по вертикали в среднем не превышает $5 . .10 \mathrm{~m}$.

Линейные остаточные коры выветривания приурочены к тектонически ослабленным участкам, которыми являются в основном узлы пересечения дайковых рифтогенных поясов с продольными зонами трещиноватости и разрывных нарушений, в том числе с зонами послойной кварцевой минерализации в палеозойских терригенных породах.

Линейные коры отличаются от площадных глубиной распространения и степенью преобразования исходных пород. Они представлены породами не только зон дезинтеграции и гидратации, но и зоны гидролиза. Мощность зоны гидролиза составляет $0,8 \ldots 39,5 \mathrm{~m}$, она представлена глинами и глинистыми песками, каолинитовыми либо существенно каолинизированными, охристыми, белесыми, зеленовато-охристыми, серовато-розовыми, по долеритам - зеленовато и голубовато-серыми, полутвердыми породами. Глины преимущественно бесструктурные, реже со слабо выраженной реликтовой сланцеватостью, в различной степени запесочены и ожелезнены.

В верхней части разреза, в зоне аэрации, коры выветривания подвергаются окислительным преобразованиям. За счет постоянной примеси гидроокислов железа, имеющих преимущественно пятнисто-полосчатый характер распределения, глины приобретают охристые оттенки. 
Установленная вертикальная мощность линейной коры выветривания, по данным бурения, превышает $68,7 \mathrm{~m}$, составляя в среднем около $30 \mathrm{~m}$.

Исследование состава примесных элементов в продуктах остаточной коры выветривания позволило выделить четыре геохимических ассоциации: 1) Mn, Fe, Co, Zn - ассоциация элементов, характерная для минералов группы карбонатов, образующихся в результате гипергенных изменений материнских пород (Со и Zn входят в состав карбонатов в качестве примеси); 2) Sn, Tl, $\mathrm{Bi}$ - элементы-примеси в пирите и гипергенном золоте; 3) P, Zn, Hf - ассоциация элементов, характеризующая геохимические особенности акцессорных минералов материнских пород - циркона, редкоземельных фосфатов; 4) As, Sb, W, $\mathrm{Au}$ - элементы-индикаторы первичной золоторудной минерализации, в качестве примесей присутствующие в составе новообразованных гипергенных пирита и карбонатов. С помощью электронной микроскопии установлено техногенное происхождение примесей вольфрама в пробах, обусловленное разрушением породоразрушающего инструмента в процессе бурения; наибольшие концентрации вольфрама характерны для интервалов с обильным содержанием щебня и дресвы кварца.

Переотложенные коры выветривания представлены глинами различного цвета, с дресвой и щебнем кварца, реже с галькой кварца, выветрелым щебнем алевролитов и песчаников палеозоя, обломками кремней, кварцитовидных песчаников и конгломератов эоцена. В аллювиальных отложениях наблюдается иногда галька черных кремней, характерная для дальнеприносных отложений. По положению в разрезе, составу пород, структуре осадков, окатанности обломков эти породы могут быть отнесены к близко- и дальнеприносным отложениям кирсановской свиты, к базальным горизонтам тайгинской свиты.

На Ушайской площади остаточная кора выветривания сформирована по песчаникам и алевролитам басандайской свиты. Мощность ее, как правило, не превышает 15 м, увеличиваясь в отдельных скважинах до 34 м.

Зона дезинтеграции представлена щебнистым, дресвяно-щебнистым материалом исходных пород, сложенных светло-серыми, голубовато-серыми мелкозернистыми песчаниками и темно-серыми, серыми алевролитами, в различной степени выветрелыми, иногда с мелким щебнем прожилкового кварца. Присутствует постоянная примесь глинистого материала. Мощность зоны дезинтеграции колеблется в пределах от 0,5 до 5 м.

В зоне гидратации преобладают темно-серые, черные, сизые с голубоватым или зеленоватым оттенком преимущественно гидрослюдистые глины с дресвой и щебнем выветрелых пород и обломками кварца. Дайки габбро-долеритов в зоне гидратации превращаются в дресву, характеризующуюся значительным количеством гидрослюд.
В зоне гидролиза преобладают жирные гидрослюдисто-каолинитовые, часто песчанистые глины преимущественно светло-бурого, светло-серого и серого цвета, иногда с голубоватым оттенком. В глинах присутствует единичный мелкий щебень кварца.

Сокращенный химический анализ 95 проб из зоны гидролиза остаточной коры выветривания показал, что в составе пород преобладают кремнезем (23...60\%, в среднем $39 \%)$, глинозем (12...22\%, в среднем $18,7 \%$ ), содержание $\mathrm{Fe}_{2} \mathrm{O}_{3}$ изменяется от 1 до 15,5 \% , составляя в среднем 4,5 \%. Породы относятся к полукислым грубодисперсным глинам со средним и высоким содержанием красящих оксидов. По имеющимся данным сокращенного химического анализа были рассчитаны основные геохимические модули, указывающие на степень химического выветривания материнских пород [3] - гидролизатный $\left(\mathrm{\Gamma M}=\left(\mathrm{Al}_{2} \mathrm{O}_{3}+\mathrm{TiO}_{2}+\mathrm{Fe}_{2} \mathrm{O}_{3}+\mathrm{FeO}\right) / \mathrm{SiO}_{2}\right)$, алюмокремниевый $\left(\mathrm{AM}=\mathrm{Al}_{2} \mathrm{O}_{3} / \mathrm{SiO}_{2}\right)$ и титановый $\left(\mathrm{TM}=\mathrm{TiO}_{2} / \mathrm{A1}_{2} \mathrm{O}_{3}\right)$ модули. В соответствии с рассчитанными значениями титанового модуля на построенной диаграмме зависимости TM- $\mathrm{TiO}_{2}$ фигуративные точки изучаемых глинистых пород преимущественно располагаются в области существенно гидрослюдистых глин. Согласно рассчитанным значениям гидролизатного (как правило, $\Gamma \mathrm{M}>0,5)$ и алюмокремниевого модулей (преимущественно, $\mathrm{AM}>0,35)$, изучаемые глинистые породы образованы в результате значительного выветривания и соответствуют зоне гидролиза остаточной коры выветривания. В соответствии со значениями ТМ и АМ определено, что образование кор выветривания происходило в гумидной климатической обстановке [3-9].

На остаточной коре выветривания залегают $n e$ реотложенные коры выветривания. В строении переотложенных кор выветривания, как правило, выделяется обогащенный золотом базальный горизонт щебнисто-глинистого состава, представленный белыми каолинитовыми глинами, дресвой и более крупными, в различной степени окатанными, обломками жильного кварца размером до 30 см в диаметре и глинизированными обломками пород средней мощностью до 2 м. Выше, в переотложенных корах, преобладают рыхлые отложения глинисто-алеврито-песчаного состава с кварцгидрослюдисто-каолинитовым цементом. В верхней глинисто-песчаной части переотложенных кор иногда устанавливается несколько уровней развития линз и прослоев песчано-дресвяного кварцевого материала в глинисто-алевритовом каолинитовом цементе. В самой верхней части переотложенные коры выветривания имеют глинистый и алеврито-глинистый каолинитовый состав и с трудом отличаются от стратифицированных отложений новомихайловской свиты глинисто-песчаного состава.

Согласно результатам сокращенного химического анализа проб из переотложенных кор выветривания, содержание кремнезема составляет 
$32,3 \ldots 42,3 \%, \quad$ в среднем $35,7 \%, \quad$ глинозем $(17,7 \ldots 19,7$, в среднем $18,4 \%)$, содержание $\mathrm{Fe}_{2} \mathrm{O}_{3}$ изменяется от 3,5 до $6,3 \%$, составляя в среднем $5 \%$, содержание $\mathrm{TiO}_{2}$ в среднем составляет $0,8 \%$. Породы относятся к полукислым грубодисперсным глинам с высоким содержанием красящих оксидов.

По имеющимся данным сокращенного химического анализа были рассчитаны основные геохимические модули, указывающие на степень химического выветривания материнских пород [3] - гидролизатный $\left(\mathrm{\Gamma M}=\left(\mathrm{Al}_{2} \mathrm{O}_{3}+\mathrm{TiO}_{2}+\mathrm{Fe}_{2} \mathrm{O}_{3}+\mathrm{FeO}\right) / \mathrm{SiO}_{2}\right)$, алюмокремниевый $\left(\mathrm{AM}=\mathrm{Al}_{2} \mathrm{O}_{3} / \mathrm{SiO}_{2}\right)$ и титановый $\left(\mathrm{TM}=\mathrm{TiO}_{2} / \mathrm{A1}_{2} \mathrm{O}_{3}\right)$ модули. В соответствии с рассчи- танными значениями титанового модуля на построенной диаграмме зависимости $\mathrm{TM}-\mathrm{TiO}_{2}$ большинство фигуративных точек изучаемых глинистых пород преимущественно располагается в области существенно гидрослюдистых глин, также фигуративные точки располагаются в области пересечения существенно гидрослюдистых и существенно монтмориллонитовых глин. Согласно рассчитанным значениям гидролизатного модуля, установлены значительные его вариации $(0,07 . . .1,54$; среднее значение $\Gamma \mathrm{M}=0,39)$, повышенные значения ГМ (больше нормы для платформенных глин в интервале $0,3 . . .0,55)$ указывают на примесь продуктов гумидного выветривания суб-
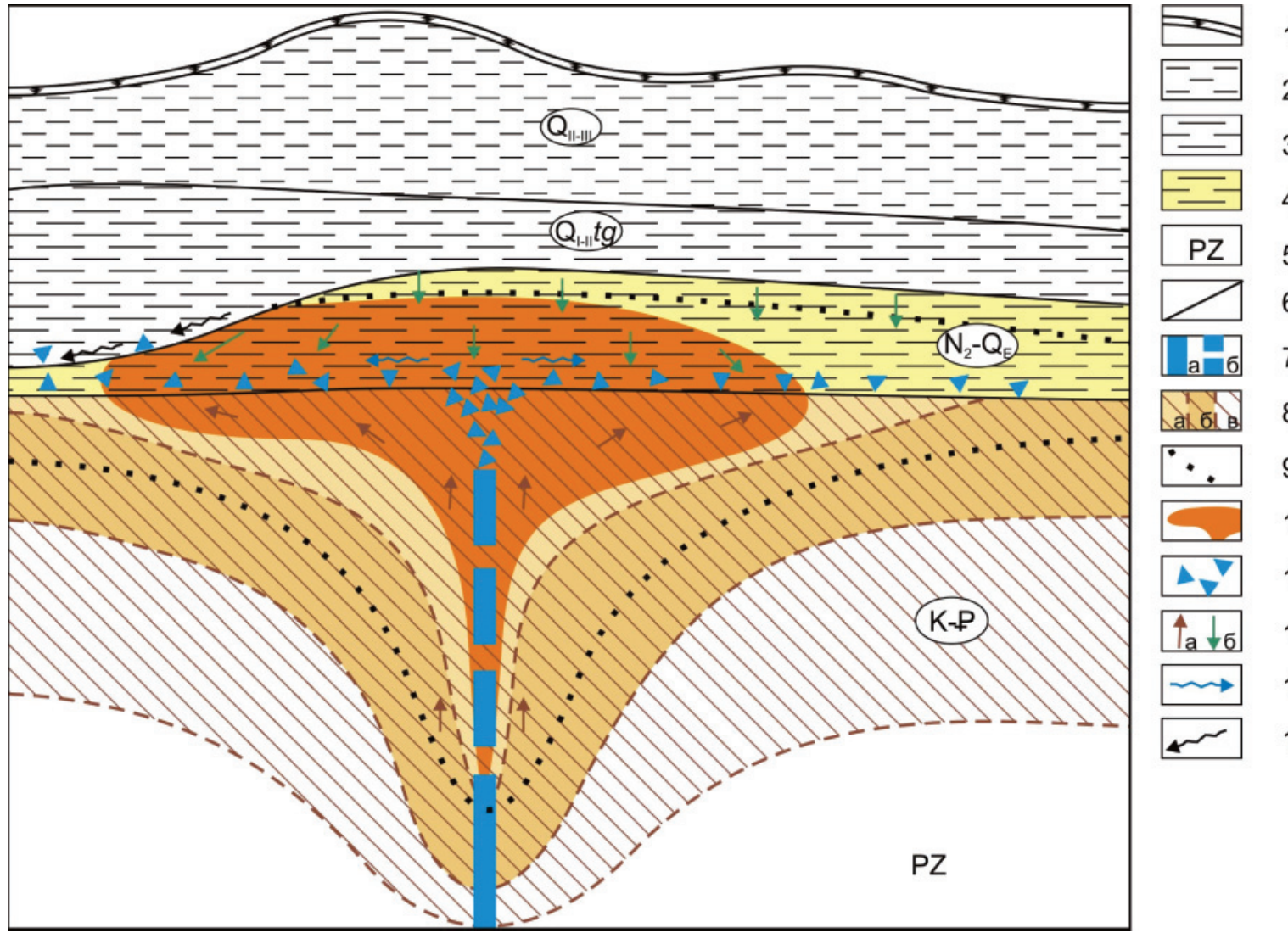

Рис. 2. Сводная модель полного профиля коры выветривания по Е.В. Черняеву [2]: 1 - почвенно-растительный слой; 2 - покровные суглинки и глины QII-III; 3 - глины, суглинки тайгинской свиты QI-IItg, в основании с дресвой квариа и с обломками кор выветривания; 4 - переотложенная кора выветривания N2-QE: глины с галькой, щебнем и дресвой квариа; 5 - породы палеозойского фундамента; 6 - геологические границы между стратиграфическими подразделениями; 7 - зоны золото-квариевой минерализащии: а) гипогенные; б) гипогенно-гипергенные, дезинтегрированные, с остаточным и наложенным гипергенным золотом; 8 - остаточная кора выветривания K-P-: а) зона гидролиза; б) зона гидратащии; в) зона дезинтеграиии; 9 - область смешения седиментационных и вадозных вод; 10 - коры выветривания с гипергенным золотом; 11 - дресва и щебень квариа; 12 - направление миграции подземных вод: а) элизионных седиментационных; б) грунтовых вадозных; 13 - направление переотложения золотоносного материала в рыхлых отложениях неогена-эоплейстоцена; 14 - направление переотложения золотоносного материала в четвертичных рыхлых отложениях

Fig. 2. Integrated model of the complete profile of the weathering crust by E.V. Chernyaev [2]: 1 is the soil; 2 is the covering loam and clay QII-III; 3 is the clay, loam of taiginskaya suite QI-IItg, in the basement with fragments of quartz and with debris of weathering crusts; 4 is the redeposited weathering crust N2-QE: clay with pebbles, rubble and gruss of quartz; 5 are the paleozoic rocks; 6 are the geological boundaries between stratigraphic subdivisions; 7 are the zones of gold-quartz mineralization: a) hypogenous; $\sigma$ ) hypogene-hypergenic, disintegrated, with residual and superimposed gold; 8 is the residual weathering crust $K-P-:$ a) hydrolysis zone; б) zone of hydration; 8 ) zone of disintegration; 9 is the area of mixing the sedimentary and vadose waters; 10 are the weathering crusts with hypergenic gold; 11 is the gruss and rubble quartz; 12 is the direction of groundwater migration: a) elysion sedimentation; б) groundwater vadose; 13 is the direction of redeposition of gold-bearing material in loose Neogene-Eopleistocene sediments; 14 is the direction of redeposition of gold-bearing material in quaternary loose sediments 
страта любого состава. Согласно рассчитанным значениям алюмокремниевого модуля $(0,05 . . .1,3$; среднее значение $\mathrm{AM}=0,32)$, изучаемые глинистые породы образованы в результате размыва гумидных кор выветривания [3-9].

Сводный разрез полного профиля коры выветривания, согласно геолого-поисковой модели Е.В. Черняева [2], представлен на рис. 2, он включает зоны дезинтеграции, гидратации и гидролиза остаточной коры выветривания и переотложенную кору выветривания. Образование кор выветривания происходит в результате смешения близповерхностных грунтовых вод нисходящей миграции и подземных седиментационных вод восходящей миграции в зоне смены поровой проницаемости осадочного чехла на трещинную проницаемость фундамента. Поступление напорных седиментационных вод из Западно-Сибирского артезианского бассейна контролируется зонами трещиноватости, вмещающими дайковые пояса, занимающие поперечное положение к границам бассейна [2].

Сокращенный гранулометрический состав кор выветривания Халдеевской и Ушайской площадей представлен в табл. 1. Зона дезинтеграции, как правило, представлена в различной степени трещиноватыми, раздробленными выветрелыми материнскими породами, при этом содержание щебнисто-дресвяной фракции превышает 50 \%, количество песчано-алевритового и глинистого материала варьирует $[10,11]$. В составе щебнисто-дресвяной фракции (>1 мм) установлены обохренные обломки выветрелых филлитовидных сланцев, алевролитов, кварца, песчаников, реже долеритов, псевдоморфозы гидроокислов железа по пириту и гетит. В зонах гидратации и гидролиза, переотложенной коре выветривания преобладают частицы пелитовой размерности.
Таблииа 1. Сокращенный гранулометрический состав продук тов коры выветривания

Table 1. Abridged size distribution of the weathering crust products

\begin{tabular}{|c|c|c|c|c|c|c|c|c|c|c|c|}
\hline \multicolumn{12}{|c|}{$\begin{array}{l}\text { Фракции (мм)/Выход фракций (\%) } \\
\text { Fractions (mm)/Output of fractions (\%) }\end{array}$} \\
\hline $\begin{array}{l}\text { щебнистая } \\
\text { rubble }\end{array}$ & \multicolumn{3}{|c|}{$\begin{array}{c}\text { дресвяная } \\
\text { grussy }\end{array}$} & \multicolumn{3}{|c|}{$\begin{array}{l}\text { песчаная } \\
\text { sand }\end{array}$} & \multicolumn{2}{|c|}{$\begin{array}{c}\text { алевритовая } \\
\text { aleurite }\end{array}$} & \multicolumn{3}{|c|}{$\begin{array}{c}\text { пелитовая ре- } \\
\text { litic }\end{array}$} \\
\hline$\stackrel{ }{\wedge}$ & $\begin{array}{ll}20 \\
0 \\
0\end{array}$ & $\begin{array}{l}1 \\
1 \\
10\end{array}$ & $\overrightarrow{1}$ & $\begin{array}{ll}10 \\
0 \\
1\end{array}$ & \begin{tabular}{l}
20 \\
\multirow{2}{*}{} \\
0 \\
1 \\
1 \\
0 \\
0
\end{tabular} & 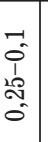 & $\begin{array}{l}0 \\
0 \\
1 \\
0 \\
0\end{array}$ & $\begin{array}{l}0 \\
0 \\
0 \\
0 \\
0 \\
0\end{array}$ & \begin{tabular}{|l|}
20 \\
8 \\
0 \\
1 \\
1 \\
0 \\
0 \\
0
\end{tabular} & $\begin{array}{l}\overrightarrow{8} \\
0 \\
0 \\
1 \\
0 \\
0 \\
0\end{array}$ & $\overrightarrow{\tilde{\sigma}}$ \\
\hline 1 & 2 & 3 & 4 & 5 & 6 & 7 & 8 & 9 & 10 & 11 & 12 \\
\hline \multicolumn{12}{|c|}{ Переотложенная кора выветривания/Redeposited weathering crust } \\
\hline \multicolumn{12}{|c|}{$\begin{array}{l}\text { существенно песчано-глинистый разрез } \\
\text { essentially sandy-argillaceous incision }\end{array}$} \\
\hline 1 & 2 & 3 & 4 & 5 & 6 & 7 & 8 & 9 & 10 & 11 & 12 \\
\hline 0,0 & 0,0 & 0,2 & 0,2 & 0,2 & & 8,9 & & 30,5 & 13,6 & 23,7 & 22,7 \\
\hline \multicolumn{12}{|c|}{$\begin{array}{l}\text { со значительной примесью щебнисто-дресвяной фракции } \\
\text { with a significant admixture of rubble and gruss }\end{array}$} \\
\hline 1 & 2 & 3 & 4 & 5 & 6 & 7 & 8 & 9 & 10 & 11 & 12 \\
\hline 13,0 & & 11,7 & & & & 12 & & & & 62,4 & \\
\hline \multicolumn{12}{|c|}{ Остаточная кора выветривания/Residual weathering crust } \\
\hline \multicolumn{12}{|c|}{ Зона гидролиза/Hydrolysis zone } \\
\hline 1 & 2 & 3 & 4 & 5 & 6 & 7 & 8 & 9 & 10 & 11 & 12 \\
\hline 0,0 & 0,0 & 1,0 & 1,3 & 1,6 & & 13,2 & & 23,6 & 15,1 & 31,9 & 12,3 \\
\hline \multicolumn{12}{|c|}{ Зона гидратации/Hydration zone } \\
\hline 1 & 2 & 3 & 4 & 5 & \begin{tabular}{l|l}
6 &
\end{tabular} & 7 & 8 & 9 & 10 & 11 & 12 \\
\hline \multicolumn{4}{|c|}{ 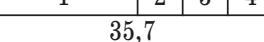 } & & \multicolumn{3}{|c|}{44,1} \\
\hline
\end{tabular}

Выделение переотложенной коры выветривания и зон остаточной коры выветривания обусловлено соотношением фракций по размерности в продуктах выветривания и процентным содержанием соответствующих минералов пелитовой фракции по разрезу, а также характером распределения, соотношением и особенностями морфологии глинистых, акцессорных минералов и золота (рис. 3).

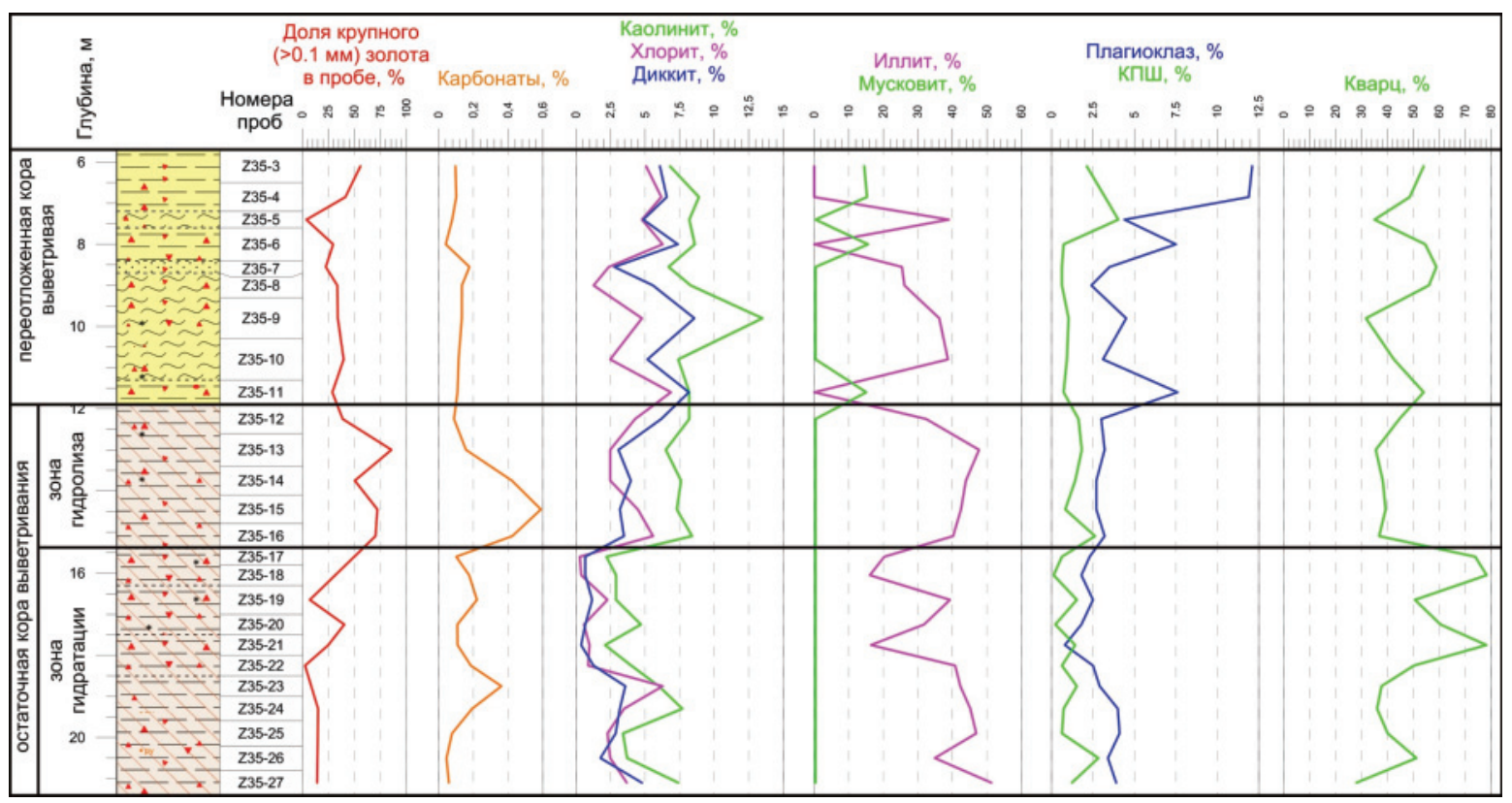

Рис. 3. Графики изменения содержания крупного золота, карбонатов и минералов пелитовой фракиии

Fig. 3. Graphs of changes in the content of large gold, carbonates and minerals of the pelite fraction 
Вещественный состав кор выветривания зависит от состава исходных пород и изменяется по разрезу. В зоне дезинтеграции породы по трещинам замещаются хлоритом, по плагиоклазам развиваются гидрослюды, калиевые полевые шпаты замещаются минералами группы каолинита. Вверх по разрезу степень изменения исходных пород возрастает, в самых верхних горизонтах остаточной коры выветривания наиболее распространенным новообразованными минералами являются каолинит, гидрослюды и гидроокислы железа. Особенно хорошо устанавливается граница между переотложенной и остаточной корой выветривания. Переотложенная кора выветривания характеризуется наибольшим разнообразием акцессорных минералов, большинство минералов тяжелой и легкой фракций окатаны, для этой части разреза характерно присутствие окатанного золота и его зерен со сглаженными вследствие транспортировки очертаниями. В остаточной коре выветривания акцессорные минералы отличаются заметным разнообразием лишь в зоне гидролиза, в зонах дезинтеграции и гидратации их общее количество снижается, при этом минералы тяжелой и легкой фракций не несут следов окатывания, золотины остаточной коры выветривания также имеют рудный облик [9-18]. Минеральный состав выделенных зон коры выветривания по данным изучения Ушайской и Халдеевской площадей близкий и отражен в табл. 2,3 .

Золото остаточной коры выветривания имеет рудный облик, большинство золотин относится к неправильному морфологическому типу. Наблюдается общая тенденция уменьшения размерности выделений золота с глубиной. Среди золотин преобладают цементационные, имеющие ажурную и комковидную формы. Интерстициальные выделения золота имеют преимущественно трёхмерную комковидную форму, с отпечатками вмещающих минералов с угловатой блестящей поверхностью, либо следы вдавливания с шагреневой поверхностью. Единичные зерна имеют чешуйчатую и пластинчатую формы. Гемиидиоморфные золотинки представлены неправильными комковидными выделениями, пластинчатыми формами, как правило, с ксеноморфными ответвлениями, реже с ограненными выступами. Идиоморфный тип представлен пластинчатыми и проволоковидными образованиями, единичными плохоограненными изометричными кристаллами золота [16].

Для переотложенной коры выветривания характерно наличие золотинок со следами транспортировки, с тенденцией снижения таких золотинок по мере перехода к подошве. Золотинки со следами транспортировки характеризуются более крупными (по сравнению с золотом «рудного» облика) размерами, имеют сглаженные очертания (иногда до совершенной степени окатанности), представлены трёхмерными изометричными, близкими к округлой форме, неправильными или несколько удлинёнными, иногда уплощенными образованиями.
Характерно наличие золотинок, обрастающих корочкой новообразованного более высокопробного золота $[19,20]$.

таблица 2. Минеральный состав и зональность пелитовой фракиии коры выветривания*

Table 2. Mineral composition and zonation of pelitic fraction of weathering crusts*

\begin{tabular}{|c|c|c|}
\hline \multicolumn{2}{|c|}{ 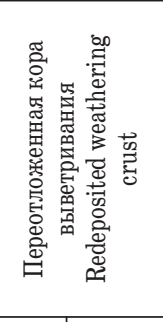 } & 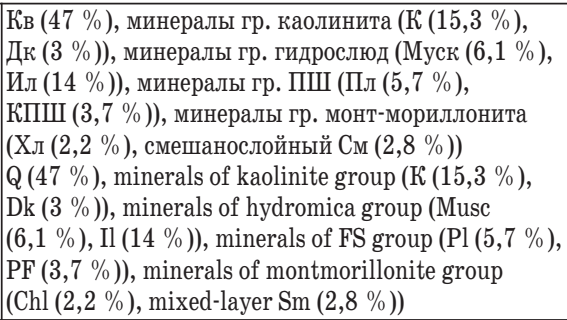 \\
\hline \multirow{3}{*}{ 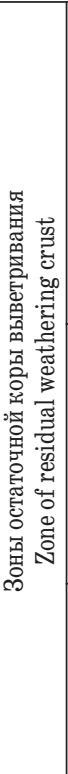 } & 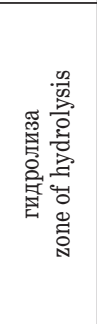 & 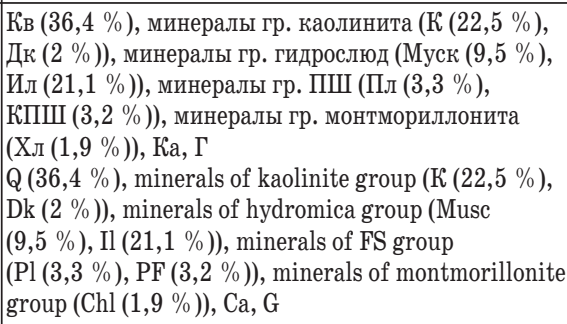 \\
\hline & 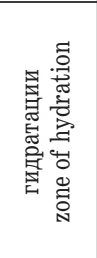 & 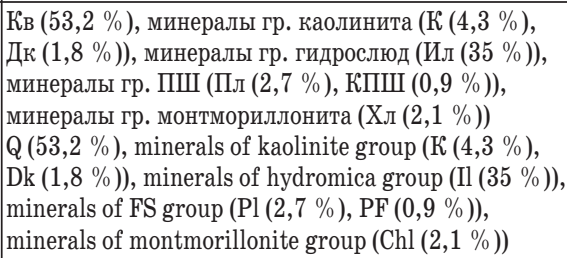 \\
\hline & 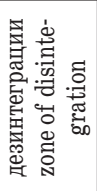 & $\begin{array}{l}\text { Кв, Ка, минералы гр. ПШ (Пл, КПШ), } \\
\text { минералы гр. гидрослюд (Муск, Ил), } \\
\text { минералы гр. монтмориллонита (Хл) } \\
\text { Q, Ca, minerals of FS group (Pl, PF), } \\
\text { minerals of hydromica group (Musc, Il), } \\
\text { minerals of montmorillonite group (Chl) }\end{array}$ \\
\hline
\end{tabular}

Кв - квари, $К$ - каолинит, Дк-диккит, Муск- мусковит, Ил иллит, ПШ - полевые шпаты, Пл - плагиоклаз, КПШ - калиевый полевой шпат, Хл-хлорит, Сл-слектит, Ка - кальцит, $\Gamma$ - гетит, гр. - группа. *В скобках среднее содержание минерала.

$Q$ - quartz, $K$ - kaolinite, Dk-dickite, Musc-muscovite, Il-illite, FS - feldspar, Pl-plagioklase, $P F$ - potassium feldspar, Chl-chlorite, $\mathrm{Sm}$ - smectite, $\mathrm{Ca}$-calcite, $\mathrm{G}$ - goethite. ${ }^{*}$ The average mineral content is indicated in parentheses.

Среди обнаруженных в переотложенной коре выветривания золотинок «рудного» облика преобладают цементационные, ажурные, кружевные, комковидные. Также присутствуют интерстициальные выделения с блестящими поверхностями отпечатков вмещающих минералов, единичные пластинчатые и чешуйчатые зерна. Идиоморфные золотинки представлены единичными плохоограненными или искаженными кристаллами с преобладанием граней октаэдра, реже встречаются брусочковидные формы и гимиидиоморфные зерна с ксеноморфными отростками и предполагаемыми недооформленными гранями.

Из сульфидов в остаточной коре выветривания постоянно присутствует пирит, для которого характерна тенденция повышения содержания от 
Таблица 3. Минеральный состав и зональность песчано-алевритовой фракиии коры выветривания

Table 3. Mineral composition and zonation sand-aleurite fraction of weathering crusts

\begin{tabular}{|c|c|c|}
\hline & & $\begin{array}{l}\text { Тяжелая фракция: Р, Сф, Лк, Т, Ц, Ф, Г, псевдоморфо- } \\
\text { зы ГО по П, П, Мгт, минералы гр. Амф, Эп, Пир, еди- } \\
\text { ничные кристаллы И, Ан, Шп, Кор, в незначительном } \\
\text { количестве - Fе-карб. Золото размерностью } \\
0,1-0,01 \text { мм - до } 114 \text { зн, >0,1 мм - до } 142 \text { зн. Легкая } \\
\text { фракция: обохренные обломки Кв, Ал, Пс, Кр, Кн, ми- } \\
\text { нералы гр. ПШ } \\
\text { Heavy fraction: R, Sph, Lk, T, C, Ph, G, pseudomorphs of } \\
\text { iron hydroxides from P, P, Mgt, minerals of Amf group, } \\
\text { of Ep group, of Pir group, single crystals I, An, Sp, Kor, } \\
\text { in small amounts - Fe-carb. Au 0,1-0,01 mm - to 114 pie-- } \\
\text { ces, >0,1 mm - to } 142 \text { pieces. Light fraction: ferruginous } \\
\text { pieces Q, Al, Ps, Fl, Cn, minerals of FS group }\end{array}$ \\
\hline \multirow{3}{*}{ 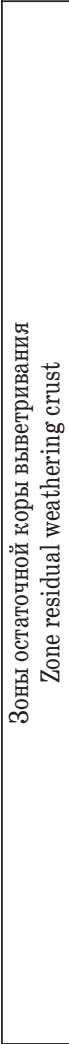 } & & $\begin{array}{l}\text { Тяжелая фракция: значительное количество ожелез- } \\
\text { ненных агрегатов Fе-карб, Р, Сф, Лк, Т, Ц, Г, псевдо- } \\
\text { морфозы ГО по П, в незначительном количестве - } \\
\text { П, Мгт, Гр, Ф. Легкая фракция: обохренные обломки } \\
\text { Кв, Ал, Пс, минералы гр. ПШ } \\
\text { Heavy fraction: R, Sph, Lk, T, C, G, pseudomorphs of } \\
\text { iron hydroxides from P, in small amounts - P, Mgt, Gr, } \\
\text { Ph. Au 0,1-0,01 mm - to } 6 \text { pieces, >0,1 mm - to 37 pie- } \\
\text { ces. Light fraction: ferruginous pieces Q, Al, Ps, Fl, Cn, } \\
\text { minerals of FS group }\end{array}$ \\
\hline & 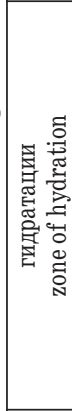 & $\begin{array}{l}\text { Тяжелая фракция: П (иногда с окисной пленкой), } \\
\text { Мгт, Ф, в незначительных количествах - Т, Р, И, Ап, } \\
\text { Ц, Fе-карб (часто ожелезненные), Г, псевдоморфозы } \\
\text { ГО по П, минералы гр. Амф, Эп. Золото размерностью } \\
0,1-0,01 \text { мм - до } 715 \text { зн, >0,1 мм - до 920 зн. Легкая } \\
\text { фракция: обохренные обломки Кв, Г-Д, Ал, Пс, мине- } \\
\text { ралы гр. ПШ } \\
\text { Heavy fraction: P (sometimes with an oxide film), Mgt, } \\
\text { Ph, in small amounts - T, R, I, Ap, C, Fe-carb (often fer- } \\
\text { ruginous), G, pseudomorphs of iron hydroxides from P, } \\
\text { minerals of Amf group, of Ep group. Au 0,1-0,01 mm - } \\
\text { to } 715 \text { pieces, >0,1 mm - to 920 pieces. Light fraction: } \\
\text { ferruginous pieces Q, G-D, Al, Ps, minerals of FS group }\end{array}$ \\
\hline & 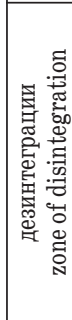 & $\begin{array}{l}\text { Тяжелая фракция: значительное количество П (часто } \\
\text { окисленого) и Мгт, единичные псевдоморфозы ГО по } \\
\text { П, Р, И, Ц, Т, Ап, Ф. Золото размерностью 0,1-0,01 мм - } \\
\text { до } 16 \text { зн, >0,1 мм - до } 3 \text { зн. Легкая фракция: обломки } \\
\text { Кв, Ал, Пс, Г-Д, минералы гр. ПШ } \\
\text { Heavy fraction: a significant number of P (often oxidiz- } \\
\text { ed) and Mgt, single pseudomorphs of iron hydroxides } \\
\text { from P, R, I, C, T, Ap, Ph. Au 0,1-0,01 mm - } \\
\text { to } 16 \text { pieces, >0,1 mm - to } 3 \text { pieces. Light fraction: } \\
\text { pieces Q, Al, Ps, G-D, minerals of FS group }\end{array}$ \\
\hline
\end{tabular}

Кв - квари, ПШ - полевые шпаты, Ал - алевролиты, Пс - песча ники, Кр - кремни, Кн - конгломераты, Г-Д - габбро-долериты, $P$ - рутил, Сф-сфен, Лк-лейкоксен, $T$ - турмалин, Ц - ииркон, $\Phi$ - фосфаты, $Г$ - гетит, ГО - гидроокислы железа, П - пирит, Мгт - магнетит, Амф - амфиболь, Эп - эпидот, Пир - пироксе ны, И - ильменит, Ан - анатаз, зн-знаков, гр. - группа.

$Q$ - quartz, FS - feldspar, Al-siltstones, $P$ - sandstones, $F l$ - flint, Cn - conglomerates, G-D - gabbro-dolerites, $R$ - rutile, Sph - sphene, Lk - leukoxene, $T$ - tourmaline, $C$ - circone, $P h$ - phosphates, $G$ - goethite, $\mathrm{Hi}$ - hydroxides of iron, $\mathrm{P}$ - pyrite, $\mathrm{Mgt}$ - magnetite, Amf - amphiboles, Ep - epidote, Pir - pyroxenes, $И$ - ilmenite, An - anatase, $\mathrm{Sp}$ - spinel, Kor - corundum, Gr - garnet, Ap - apatite, Fe-carb-ferruginous carbonates.

единичных зерен до значительных концентраций в тяжелой фракции минералов по направлению от зоны гидролиза к зоне дезинтеграции. Подобным образом ведет себя в остаточной коре и магнетит. По результатам химического анализа методом ИСП-масс-спектрометрии содержание золота в мо- номинеральных фракциях интенсивно окисленного первичного пирита в зоне гидратации остаточной коры выветривания достигает 258 г/т, в монофракциях пирита, полностью замещенного гидроокислами железа в зоне дезинтеграции, содержание золота не превышает десятых долей г/т [21].

Практически повсеместно присутствуют сферические агрегаты железистых карбонатов различной степени ожелезнения, с наибольшей концентрацией в верхней части остаточной коры - в зоне гидролиза, с глубиной количество железистого карбоната снижается и в зоне дезинтеграции карбонат представлен кальцитом. По результатам химического анализа методом ИСП-масс-спектрометрии содержание золота в монофракции гипергенного железистого карбоната в зоне гидролиза остаточной коры выветривания достигает 0,778 г/т, в зонах гидратации и дезинтеграции содержание золота в карбонатах не превышает сотых долей процента [22].

Титановые минералы - ильменит и рутил - в верхней части остаточной коры выветривания (зона гидролиза) частично либо полностью замещаются лейкоксеном, в переотложенной коре выветривания присутствуют единичные зерна анатаза и сфен.

Минералы группы редкоземельных фосфатов, турмалин и циркон присутствуют во всех частях разреза. Присутствие апатита отмечается только в зонах гидратации и дезинтеграции остаточной коры выветривания.

Из породообразующих минералов в тяжелой фракции встречаются минералы группы амфиболов, пироксенов и эпидота, при этом они встречаются в нижней части остаточной коры и в переотложенной коре выветривания. Из породообразующих минералов в легкой фракции присутствует кварц, минералы группы полевых шпатов, эти минералы встречаются во всех зонах профиля коры выветривания.

Обломки пород в остаточной коре выветривания представлены песчаниками, алевролитами, габбро-долеритами, в переотложенной коре выветривания дополнительно присутствуют кремни и конгломераты.

\section{Выводы}

1. Установлено, что в Томь-Яйском междуречье коры выветривания очень широко развиты, они подразделяются на остаточные и переотложенные. Остаточные коры выветривания представлены линейным и площадным морфологическими типами.

2. Продукты выветривания представлены песчано-алевритовым, глинистым и щебнисто-дресвяным материалом, с преобладанием песчаной и алеврито-глинистой составляющей.

3. Корообразование, согласно значениям рассчитанных геохимических коэффициентов, происходило в обстановке гумидного климата. Остаточные коры выветривания имеют монтморил- 
лонит-каолинит-гидрослюдистый состав. В строении полного профиля выделяются зоны: дезинтеграции, гидратации и гидролиза. В сокращенном профиле зоны гидратации и гидролиза могут отсутствовать.

4. Выявлена минералого-геохимическая зональность профиля выветривания, выражающаяся в закономерном изменении по разрезу количества и состава глинистых минералов, карбонатов, пирита, золота и других минералов.

- В распределении глинистых минералов по зонам остаточной коры выветривания существует следующая тенденция - по мере перехода от зоны дезинтеграции к зоне гидролиза растет концентрация минералов группы каолинита, гидрослюд и снижается количество минералов группы монтмориллонита, а также кварца и полевых шпатов. Для переотложенной коры выветривания характерно значительное количество кварца, присутствие минералов группы каолинита, гидрослюд, в небольших количествах полевых шпатов, минералов группы монтмориллонита.

- В пробах из переотложенной коры выветривания наблюдается наибольшее разнообразие минералов. Золото и многие минералы

\section{СПИСОК ЛИТЕРАТУРЫ}

1. Парначев В.П., Парначев С.В. Геология и полезные ископаемые окрестностей города Томска. Материалы к полевой геологической экскурсии: справочное пособие. - Томск: ТГУ, 2010. - 144 c.

2. Черняев Е.В. Генезис и золотоносность кор выветривания Томского района // Цветные металлы и минералы: Сборник тезисов докладов восьмого международного конгресса. - Красноярск, 2016. - С. $336-337$.

3. Интерпретация геохимических данных / Е.В. Скляров, Д.П. Гладкочуб, Т.В. Донская, А.В. Иванов, Е.Ф. Летникова, А.Т. Миронов, И.Г. Бараш, В.А. Буланов, А.И. Сизых / под ред. Е.В. Склярова. - М: Интернет Инжиниринг, 2001. - 288 с.

4. Геохимия рудных элементов в процессах выветривания, осадконакопления и катагенеза. Сборник научных трудов / под ред. В.М. Гавшина. - Новосибирск: Институт геологии и геофизики СО АН СССР, 1979. - 162 с.

5. Литолого-геохимические особенности отложений Усть-Одинского опорного разреза верхнего неоплейстоцена Иркутского амфитеатра Сибирской платформы / В.В. Иванова, А.А. Щетников, И.А. Филинов, С.В. Вещева, А.Ю. Казанский, Г.Г. Матасова // Литология и полезные ископаемые. - 2016. - № 3. C. $215-232$.

6. Маслов А.В. Осадочные породы: методы изучения и интерпретации полученных данных. - Екатеринбург: Изд-во УГГУ, 2005. -289 c.

7. Мельничук 0.Ю. Глинистые породы верхнедевонской кодинской свиты (Восточный склон Среднего Урала): Минералогия и химический состав, палеореконструкции // Ежегодник-2015. Екатеринбург: Тр. ИГГ Ур0 РАН, 2016. - Вып. 163. - С. 51-57.

8. Юдович Я.Э., Кетрис М.П. Геохимические индикаторы литогенеза (литологическая геохимия). - Сыктывкар: Геопринт, 2011. $-742 \mathrm{c}$.

9. Clift P.D., Wan Sh., Blusztajn J. Reconstructing chemical weathering, physical erosion and monsoon intensity since $25 \mathrm{Ma}$ in переотложенной коры выветривания в различной степени окатаны. В остаточной коре выветривания акцессорные минералы отличаются заметным разнообразием лишь в зоне гидролиза, в зонах дезинтеграции и гидратации их общее количество невелико, при этом минералы тяжелой и легкой фракций не несут следов окатывания, золотины остаточной коры выветривания также имеют «рудный» облик.

- Из сульфидов в остаточной коре выветривания постоянно присутствует пирит, для которого характерна тенденция уменьшения содержания от значительных концентраций в зоне дезинтеграции до единичных зерен в зоне гидролиза остаточной коры выветривания.

- Практически повсеместно присутствуют сферические агрегаты железистых карбонатов, с наибольшей концентрацией в зоне гидролиза остаточной коры, с глубиной количество железистого карбоната снижается.

Работа выполнена при финансовой поддержке РФФИ (грант № 18-45-700019) и в рамках гранта Програмль повышения конкурентоспособности Томского политехнического университета.

the northern South China Sea: a review of competing proxies // Earth-Science Reviews. - 2014. - V. 130. - P. 86-102.

10. Попова Н.Н. Коры выветривания участка Каспа (Восточный Саян) и их минерагения // Инжиниринг\&Технологии. 2008. - Вып. 3. - № 1. - С. 234-246.

11. Heim D. Tone und Tonminerale. - Stuttgart: F.Enke, 1990. $157 \mathrm{p}$.

12. Казанский Ю.П. Выветривание и его роль в осадконакоплении / под ред. В.П. Казаринова. - М: Наука, 1969. - 126 с.

13. Калинин Ю.А., Росляков Н.А., Прудников С.Г. Золотоносные коры выветривания юга Сибири. - Новосибирск: Гео, 2006. $339 \mathrm{c.}$

14. Казаков П.В. Нетрадиционные типы экзогенных месторождений золота // Геологический сборник № 11. Информационные материалы. - Уфа: ДизайнПресс, 2014. - 256 с.

15. The dynamics of gold in regolith change with differing environmental conditions over time / R. Anand, M. Lintern, R. Hough, R. Noble, M. Verrall, W. Salama, J. Balkau, N. Radford / / Geology. - 2017. - V. 45. - № 2. - P. 127-130.

16. Larizzatti J.H., Oliveira S.M.B., Butt C.R.M. Morphology and composition of gold in a lateritic profile, Fazenda Pison «Garimpo", Amazon, Brazil // Journal of South American Earth Sciences. - 2008. - V. 25. - P. 359-376.

17. Niggli P. Gesteine und Minerallagerstätten. Band 2. Exogene Gesteine und Minerallagerstätten. - Basel: Birkhäuser, 1952. $557 \mathrm{~s}$.

18. Schmitz M. Bedingungen, Prozesse und Stoffdynamik der Bildung tertiärer kaolinitischer Tonlagerstätten in Sachsen und Sachsen-Anhalt und deren Auswirkungen auf die anwendungstechnischen Eigenschaften der Rohstoffe. - Berlin: Technische Universität Berlin, 2008. - $277 \mathrm{~s}$.

19. Nair N.G.K., Santosh M., Mahadevan R. Lateritisation as a possible contributor to gold placers in Nilambur Valley, Southwest India // Chem. Geol. - 1987. - V. 60. - № 1-4. - P. 309-315.

20. Biological and Geochemical Development of Placer Gold Deposits at Rich Hill, Arizona, USA / E.B. Melchiorre, P.M. Orwin, 
F. Reith, M.A.D. Rea, J. Yahn, R. Allison. - Minerals. - 2018. V. 8. - Iss. 2. - P. 56-75.

21. Dating paleochannel iron ore by (U-Th)/He analysis of supergene goethite, Hamersley province, Australia / J.A. Heim, P.M. Vasconcelos, D.L. Schuster, K.A. Farley, G. Broadbent // Geology. 2006. - V. 34. - P. 173-176.

22. Янченко 0.М. Карбонаты золотоносных кор выветривания Малоушайской зоны // Проблемы геологии и освоения недр: тру- ды XXI Международного симпозиума им. академика М.А. Усова студентов и молодых ученых, посвященного 130 летию со дня рождения профессора М.И. Кучина. - Томск, 3-7 апреля 2017. - Томск: Изд-во ТПУ, 2017. - Т. 1. C. $193-194$.

Поступила 23.10.2018 2.

\section{Информация об авторах}

Янченко О.М., аспирант Инженерной школы природных ресурсов Национального исследовательского Томского политехнического университета.

Ворошилов В.Г., доктор геолого-минералогических наук, профессор Инженерной школы природных ресурсов Национального исследовательского Томского политехнического университета.

Tuлкин T.B., кандидат геолого-минералогических наук, доцент отделения геологии Инженерной школы природных ресурсов Национального исследовательского Томского политехнического университета.

Зиаии M., PhD, доцент Шахрудского технологического университета. 
UDC 553.411+551.311.231

\title{
MINERAL-GEOCHEMICAL ZONALITY OF GOLDEN-BEARING WEATHERING CRUST OF THE TOM-YAYA INTERFLUVE
}

\author{
Olga M. Yanchenko', \\ olmininayanchenko@mail.ru \\ Valery G. Voroshilov', \\ v_g_v@tpu.ru \\ Timofey V. Timkin', \\ timkin@tpu.ru \\ Mansour Ziaii' ${ }^{2}$ \\ m.ziaii47@gmail.com \\ 1 National Research Tomsk Polytechnic University, \\ 30, Lenin Avenue, Tomsk, 634050, Russia. \\ 2 Shahrood University of Technology, \\ Bolvar Daneshka, Shahrood, 3619995161, Iran.
}

The relevance. Weathering crusts of the Tom-Yaya interfluve can be the objects of commercial gold mining. Weathering crusts are widespread in the Tom-Yaya interfluve, their gold content was established, but the structure, mineral composition and geochemical features have not been studied enough.

The main aim of the research is to identify mineral and geochemical zonation of weathering crusts of the Tom-Yaya interfluve to solve the genesis issues and develop the criteria for predicting their gold content.

Object: weathering crusts on the rocks of the Paleozoic basement of the Tom-Yaya interfluve.

Methods. Crystal morphological features of gold and satellite minerals, paragenetic associations with ore and vein minerals were analyzed microscopically under a binocular, in reflected light, chemical composition of minerals was studied by inductively coupled plasmaatomic emission mass spectrometry (ICP-AES/MS), X-ray fluorescence microscope HORIBA Scientific XGT-7200, on a scanning electron microscope TESCAN VEGA 3 SBU with EMF OXFORD X-Max 50. Reduced chemical composition of weathering products was determined by inductively coupled plasma-atomic emission mass spectrometry. Mineral composition of pelite fraction was determined by X-ray diffraction analysis using a D8 Advance diffractometer from Bruker. The authors have carried out the reduced particle size analysis of weathering products in different zones of the profile.

Results. The authors identified the residual and redeposited weathering crusts in the Tom-Yaya interfluve. The weathering products are sandy-silty, clayey and gravelly-aggregate, with a predominance of sandy and silty-clayey constituents. The authors determined the composition and distribution of section clay minerals, carbonates, pyrite, gold and other minerals. Residual weathering crusts have montmorillonite-hydromica-kaolinite composition. In the structure of the complete profile, the following zones: 1) disintegration, 2) hydration and 3) hydrolysis, are distinguished. The mineral-geochemical characteristics of the isolated zones are given. Based on the abbreviated chemical analysis, the main geochemical modules were calculated.

Key words:

Residual weathering crust, redeposited weathering crust, gold, mineral-geochemical zonality, Tom-Yaya interfluve.

The research was financially supported by the RFBR grant no. 18-45-700019.

\section{REFERENCES}

1. Parnachev V.P., Parnachev S.V. Geologiva i poleznye iskopaemye okrestnostey goroda Tomska [Geology and mineral resources around Tomsk]. Materialy $k$ polevoy geologicheskoy ekskursii: spravochnoe posobie [Materials for the field geological excursion: reference book]. Tomsk, Tomsk State University Publ., 2010. $144 \mathrm{p}$.

2. Chernyaev E.V. Genezis i zolotonosnost kor vyvetrivaniya Tomskogo rayona [Genesis and mineralization of weathering mantle of Tomsk region]. Tsuetnye metally i mineraly: sbornik tezisov dokladov vosmogo mezhdunarodnogo kongressa [Non-ferrous metals and minerals: Book of abstracts of the eighth international congress]. Krasnoyarsk, 2016. pp. 336-337.

3. Sklyarov E.V., Gladkochub D.P., Donskaya T.V., Ivanov A.V., Letnikova E.F., Mironov A.T., Barash I.G., Bulanov V.A., Sizykh A.I. Interpretatsia geokhemicheskikh dannykh [Interpreta- tion of geochemical data: Textbook. allowance]. Ed. by E.V. Sklyarov. Moscow, Internet Ingeniring Publ., 2001. 288 p.

4. Geokhimiya rudnykh elementov v protsessakh vyvetrivania, osadkonakoplenia i katageneza. Sbornik nauchnykh trudov [Geochemistry of ore elements in weathering, sedimentation and catagenesis. Collection of scientific papers]. Ed. by V.M. Gavshin. Novosibirsk, S0 RAN Publ., 1979. 162 p.

5. Ivanova V.V., Shetnikov A.A, Filinov I.A., Vesheva C.V., Kazanski A.Yu., Matasova G.G. Litologo-geokhimicheskie osobennosti otlozheny Ust-Odinskogo opornogo razreza verkhnego neopleystotsena Irkutskogo amfiteatra Sibirskoy platformy [Litogeochemistry of rocks of the Upper Neopleistocene Ust-Oda reference section in the Irkutsk Amphitheater of the Siberian Platform]. Lithology and minerals, 2016, no. 3, pp. 179-194.

6. Maslov A.V. Osadochnye porody: metody izucheniya i interpretatsii poluchennykh dannykh [Sedimentary rocks: methods for stu- 
dying and interpreting the data]. Ekaterinburg, UGGU Publ. house, 2005. $289 \mathrm{p}$.

7. Melnichuk 0.Yu. Glinistye porody verkhnedevonskoy kodinskoy suity (Vostochny sklon Srednego Urala): Mineralogiya i khi micheskiy sostav, paleorekonstruktsii [Clay rocks of the Upper Devonian Kodin Formation (Eastern slope of the Middle Urals): Mineralogy and chemical composition, paleoreconstructions]. Ezhegodnik-2015 [Yearbook 2015]. Yekaterinburg, Institute of Geology and Geochemistry of the Ural Branch of the Russian Academy of Sciences, 2016. Iss. 163, pp. 51-57.

8. Yudovich Ya.E., Ketris M.P. Geokhimicheskie indikatory litogeneza (litologicheskaya geokhimiya) [Geochemical Indicators of Lithogenesis]. Syktyvkar, Geoprint Publ., 2011. 742 p.

9. Clift P.D., Wan Sh., Blusztajn J. Reconstructing chemical weathering, physical erosion and monsoon intensity since $25 \mathrm{Ma}$ in the northern South China Sea: a review of competing proxies. Earth-Science Reviews, 2014, vol. 130, pp. 86-102.

10. Popova N.N. Kory vyvetrivaniya uchastka Kaspa (Vostochny Sayan) i ikh minerageniya [Residual Soils of the Kasp Area (The Eastern Sayany) and their Minerageny]. Journal of Siberian Federal University. Engineering \& Technology, 2008, Iss. 3, no. 1, pp. 234-246.

11. Heim D. Tone und Tonminerale. Stuttgart, F. Enke, 1990.157 p.

12. Kazanskiy Yu.P. Vyvetrivanie i ego rol v osadkonakoplenii [Weathering and its role in sedimentation]. Ed. by V.P. Kazarinov. Moscow, Nauka Publ., 1969. 126 p.

13. Kalinin Yu.A., Roslyakov N.A., Prudnikov S.G. Zolotonosnye kory vyvetrivaniya yuga Sibiri [Gold-bearing weathering crust of the south of Siberia]. Novosibirsk, Geo Publ., 2006. 339 p.

14. Kazakov P.V., Kazakov P.V. Netraditsionnye tipy ekzogennykh mestorozhdeniy zolota [Non-traditional types of exogenous gold deposits]. Geologicheskiy sbornik № 11. Informatsionnyye materialy [Geological collection № 11. Information materials]. Ufa, Design Press, 2014. 256 p.

15. Anand R., Lintern M., Hough R., Noble R., Verrall M., Salama W., Balkau J., Radford N. The dynamics of gold in regolith change with differing environmental conditions over time. Geology, 2017, vol. 45, no. 2, pp. 127-130.

16. Larizzatti J.H., Oliveira S.M.B., Butt C.R.M. Morphology and composition of gold in a lateritic profile, Fazenda Pison «Garim- po", Amazon, Brazil. Journal of South American Earth Sciences, 2008, vol. 25, pp. 359-376.

17. Niggli P. Gesteine und Minerallagerstätten. Band 2. Exogene Gesteine und Minerallagerstätten [Rocks and mineral deposits. Vol. 2. Exogenous rocks and mineral deposits]. Basel, Birkhauser, 1952.557 p. In Ger.

18. Schmitz M. Bedingungen, Prozesse und Stoffdynamik der Bildung tertiärer kaolinitischer Tonlagerstätten in Sachsen und Sachsen-Anhalt und deren Auswirkungen auf die anwendungstechnischen Eigenschaften der Rohstoffe [Conditions, processes and material dynamics of the formation of tertiary kaolinitic clay deposits in Saxony and Saxony-Anhalt and their effects on the application properties of the raw materials]. Berlin, Technical University Berlin, 2008. 277 p. In Ger.

19. Nair N.G.K., Santosh M., Mahadevan R. Lateritisation as a possible contributor to gold placers in Nilambur Valley, Southwest India. Chem. Geol., 1987, vol. 60, no. 1-4, pp. 309-315.

20. Melchiorre E.B., Orwin P.M., Reith F., Rea M.A.D., Yahn J., Allison R. Biological and Geochemical Development of Placer Gold Deposits at Rich Hill, Arizona, USA. Minerals, 2018, vol. 8, Iss. 2, pp. 56-75.

21. Heim J.A., Vasconcelos P.M., Schuster D.L., Farley K.A., Broadbent G. Dating paleochannel iron ore by (U-Th)/He analysis of supergene goethite, Hamersley province, Australia. Geology, 2006, vol. 34, pp. 173-176.

22. Yanchenko 0.M. Karbonaty zolotonosnykh kor vyvetrivaniya Maloushayskoy zony [Carbonates of gold-bearing weathering crusts of the Maloushayskaya zone]. Problemy geologii i osvoyenya nedr. Trudy XXI Mezhdunarodnogo simpoziuma imeni akademika M.A. Usova studentov i molodykh uchenykh, posvyashchennogo 130-letiyu so dnya rozhdeniya professora M.I.Kuchina [Problems of geology and subsoil development. Proc. of the $21^{\text {st }}$ International Symposium of Academician M.A. Usov, students and young scientists, dedicated to the $130^{\text {th }}$ anniversary of the birth of Professor M.I. Kuchin]. Tomsk, April 3-7 2017. Tomsk, TPU Publ. house, 2017. Vol. 1, pp. 193-194.

Received: 23 October 2018.

\section{Information about the authors}

Olga M. Yanchenko, postgraduate student, National Research Tomsk State University.

Valery G. Voroshilov, Dr. Sc., professor, National Research Tomsk Polytechnic University.

Timofey V. Timkin, Cand. Sc., associate professor, National Research Tomsk Polytechnic University.

Mansour Ziaii, PhD, associate professor, Shahrood University of Technology. 